\title{
Conceptual Understanding of Excretory System: Implementing Cooperative Integrated Reading and Composition Based on Scientific Approach
}

\author{
Rizhal Hendi Ristanto* \\ Department of Biology Education, Universitas Negeri Jakarta, Rawamangun Muka Street, \\ East Jakarta, Jakarta, Indonesia ORCID: 0000-0001-8655-2030
}

Sri Rahayu

Department of Biology, Universitas Negeri Jakarta, Rawamangun Muka Street, East Jakarta, Jakarta, Indonesia ORCID: 0000-0002-7050-0583

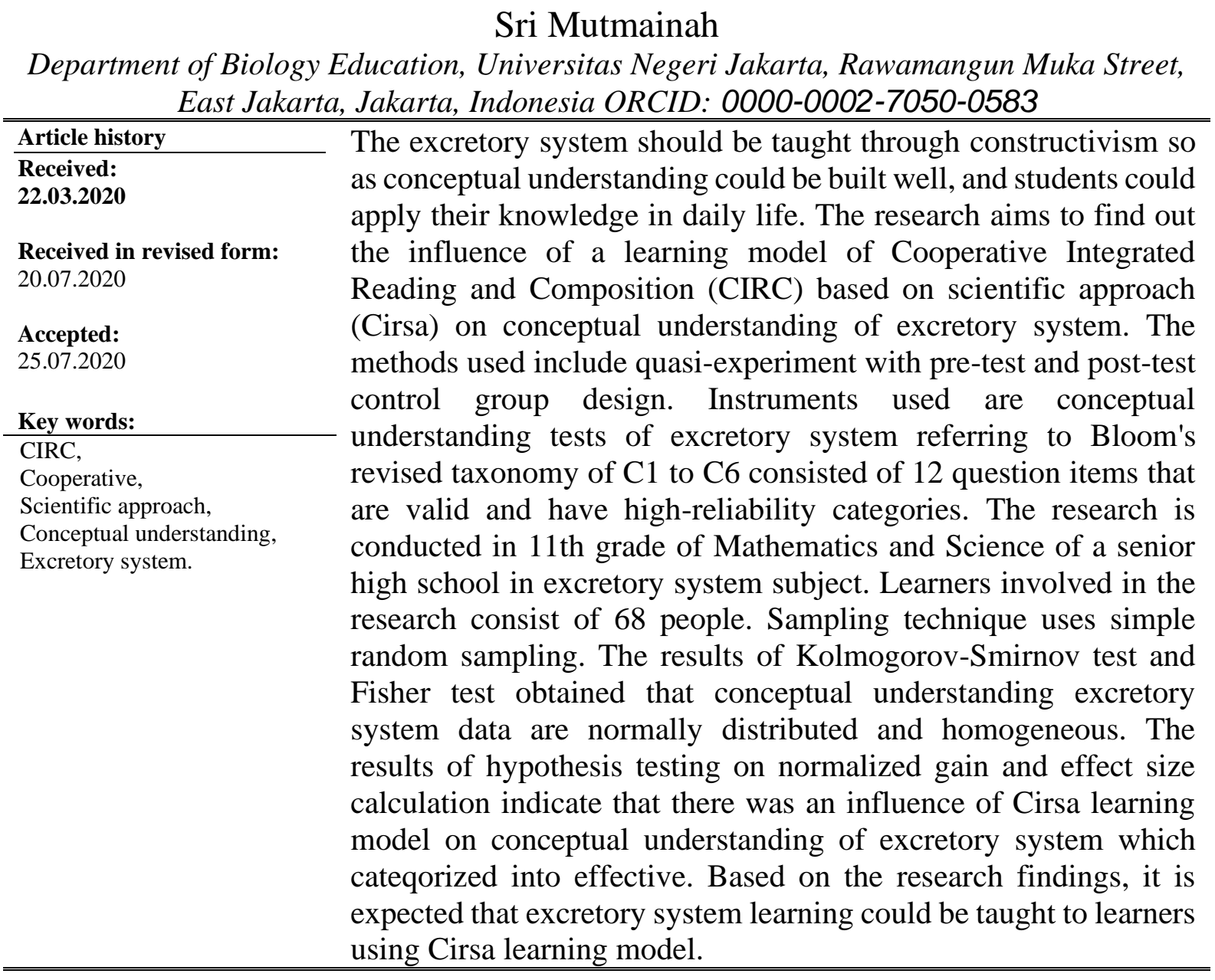

*Correspondency: rizhalhendi@unj.ac.id 


\section{Introduction}

In the $21^{\text {st }}$ century, all skill aspects experience development such as critical thinking skills, problem-solving, and collaboration that become important competences in facing the $21^{\text {st }}$ century (Daryanto \& Karim, 2017; Djamahar et al., 2018; Ichsan, at al., 2019). In this century, learners must be equipped with abilities to process and use information appropriately and effectively (Ristanto, et al., 2018a; Sele, 2019). A learning activity that conditions learners to face the century's demand is integrated reading and writing (Darmawan et al., 2019; Hariyadi \& Corebima, 2019). The reading and writing activities provide opportunities for learners to understand and interpret content substance, to logically compile ideas, express the idea clearly, and organize the idea in interesting ways (Djamahar et al., 2019; Ristanto et al., 2018b; Tamaya, Suyono \& Roekhan, 2018).

One subject that involves learners to read actively in learning is biology. Cimer (2012) opined that biology is a science that comprises abstract concepts causing learners to face difficulties in understanding the concept. Biology is a complex subject since it contains a variety of content explained using related and integrated concepts; thus, understanding one concept is not enough without understanding another concept (Maurisa \& Abdullah, 2016; Lestari et al., 2019). Therefore, skills are needed to understand the concept, and one of them is reading.

Reading is a language skill that must be learned since, through reading, someone could develop their writing and skill abilities and increase vocabulary (Al Mansour \& Al Shorman, 2014; Bustami et al., 2019). Reading involves complex skills that could make someone understand the reading. Based on a survey by UNESCO in 2012, interest in reading among Indonesian people is in the second-lowest of 61 countries. It indicates that reading interest index in Indonesia only 0.001 , which means that for every 1000 people, only one person who has an interest in reading (Hayati, Zubaidah \& Mahanal, 2015). The research result by PISA in 2015 shows that the reading level among Indonesian students is in the $69^{\text {th }}$ of 76 PISA member countries (OECD, 2017).

The low interest to read becomes one of the issues in Indonesia's education (Djamahar et al., 2018; Ristanto et al., 2017). The issue affects education quality, and the concern is that it could bring bad influence on cognitive learning outcomes (Hayati et al., 2015; Ristanto et al., 2018b). Reading activities could develop intellectual and add knowledge and insight since, through reading, one will gain information and new knowledge and foster critical thinking ways (Prawita \& Prayitno, 2019). If students have a high reading interest, the knowledge and way of thinking will increase (Hayati et al., 2015; Bustami et al., 2019).

Understanding is students ability to obtain meaning of a concept and could explain it in its language. Conceptual understanding should be considered in learning to achieve the learning process (Sastrika, Sadia \& Muderawan, 2013; Ristanto et al., 2018a). Conceptual understanding could solve problems related to the misconception (Hamdani, Kurniati \& Sakti, 2012; Yunanda et al., 2019). In biology learning, concept understanding is indispensable since it facilitates learners to understand the concept. Efforts to improve conceptual understanding in the learning process could be made by improving quality, which is using an appropriate learning model (Trilipi et al., 2019). The $21^{\text {st }}$ century requires a learning model that allows learners to be active. One of the learning models is a cooperative learning model. The model emphasizes group learning (Ilahi, 2016). It focuses on group work to discuss and solve problems.

Cooperative model has several types, and one of them is Cooperative Integrated Reading and Composition (CIRC), learning model. The CIRC model is one of the cooperative models 
developed by Steven and Slavin at the end of 1980. The model was initially applied for highclass reading and writing integrated activities at primary school (Hayati et al., 2015). CIRC model involves learners to be active in a learning process through activities of reading, discussion, concept finding and rewriting it with opinion and reflection (Gupta \& Ahuja, 2014; Ristanto et al., 2018; Djamhar et al., 2019). The learning model is a group-centered learning model that is designed to develop reading, writing, and language skill (Durukan, 2011; Mustafa \& Samad, 2015).

The scientific approach in learning involves process skills such as observe, ask, experiment, associate, and communicate (Hosnan, 2014; Djamahar et al., 2019). The approach has some advantages; namely, it is a learner-centered; it builds concept and develops learners' intellectual and characters (Daryanto \& Karim, 2017; Ristanto \& Djamhar, 2019). Based on the requirement of the 2013 Curriculum, a learning model is required that could improve reading ability, thus capable of understanding biology learning. Therefore, the CIRC model based on a scientific approach known as Cirsa is expected to be able to improve learners' concept understanding so as they could be actively involved in the reading activity, and misconception in concept understanding could be avoided. Excretory system content has related concepts, processes, and events, and it will be hard to understand if it is delivered using a conventional learning model (Masupah, Hidayat \& Latifah, 2017). Based on the description, research is required on the influence of CIRC learning model based on scientific approach or Cirsa on learner concept understanding in excretory system content.

\section{Conceptual Understanding of Excretory System}

Conceptual understanding has an element of learner ability in interpreting and explaining the meaning of a concept in its language (Kurniawan, 2013; Gunel, Hand, \& McDermott, 2009). Conceptual understanding is needed to achieve learning since it could solve problems related to misconceptions and reduce mistakes in the learning process to obtain the best learning outcome (Hamdani, Kurniati \& Sakti, 2012). Learners could understand a concept if they are active in the learning process including in finding a concept and argues against the concept (Aryulina, 2009). Concept understanding could assist learners in identifying, solving problems, and drawing a conclusion.

Based on Bloom's revised taxonomy, according to Anderson \& Krathwohl (2001), conceptual understanding could be measured in cognitive levels of remembering, understanding, applying, analyzing, evaluating, and creating. Remembering is ability to restating knowledge stored in long-term memory (Faisal, 2015). Understanding is ability to understand a concept in written or oral forms. Applying is ability to perform something and apply a concept. Analyzing is ability to connect between concepts to obtain understanding (Gunawan \& Palupi, 2016; Supriyatin et al.,2019). Evaluating is ability to make a decision based on certain criteria. Creating is ability to combine and compile elements into a new form (Faisal, 2015).

Based on the 2013 Curriculum in Indonesia, the basic competence of excretory system content includes in basic competence (Code 3.9), which is analyzing the relationship between organ structures in excretory system and connecting them to excretory process so that it could explain mechanisms and functions that likely to occur in human excretory system through literature study, observation, experiment, and simulation. Indicators that must be achieved in the basic competence include explaining the function of excretory system, identifying human excretory system organs, analyzing the link between nephron tissue structure in kidney along with its bioprocess and functions, analyzing the link between liver tissue structure along with its 
bioprocess and functions, analyzing the link between lung tissue structure along with its bioprocess and functions, analyzing the link between skin tissue structure along with its bioprocess and functions and analyzing abnormalities or disorders in the excretory system. Students would find difficulties on the skill of analyzing excretory system (Ristanto, et al., 2020; Djamahar, et al., 2020). Analyzing skills, which is inculding into high order thingking (Supriyatin, et al., 2019; Miarsyah, et al., 2020), is needed to make students to think and realistically anwer difficult question as well as solve problems (Nabilah, et al., 2019). Excretory learning has already assumed as complicated by students. Book as learning source unfortunately might create misconception about the system (Hutagaol \& Harsono, 2016). Some information regarding structure and function of excretory system also part of students difficulties. (Luzyawati \& Hidayah, 2019). Students' misconception on excretory system could be solve by contructivism- based learning (Rahmawati, et al., 2015).

\section{CIRC Learning Model}

Cooperative Integrated Reading and Composition (CIRC) learning model is a cooperative learning model developed by Steven and Slavin in 1980. The model develops reading and writing skills (Durukan, 2011; Ristanto et al., 2018b). It emphasizes reading and writing activities (Zubaidah \& Corebima, 2016). Gupta \& Ahuja (2014) argue that CIRC learning model stresses training learners to be actively involved in learning process through such activities as reading, discussion, concept finding, and rewriting it with opinion and reflection. The learning model underlines active learning in group cooperation to solve a problem (Huang, Liao, Huang \& Chen, 2014; Remli et al., 2019). It involves learners to be active in reading activity both individually and in group and rewrite it with their own words (Djamhar et al., 2019).

\section{Scientific Approach}

Scientific approach is a learning approach that direct learners to be active in understanding concept, identifying problems, formulating problems, formulating a hypothesis, collecting data, analyzing data, drawing conclusion and communicate (Hosnan, 2014; Djamhar et al., 2019). Scientific approach has the following characteristics: 1) it is a learner-centered, 2) it involves scientific process skill and concept building, 3) it involves cognitive process in intellectual development with high-level way of thinking and 4) it develops learners' characters (Ristanto \& Djamhar, 2019; Nurdyansyah \& Fahyuni, 2016). It uses scientific approach to obtain information without dependence on the teacher who acts as a facilitator (Zainudin, \& Istiyono, 2019).). In this case, learners obtain information from various sources. There are five steps in applying scientific approach in teaching and learning process, including observe, ask, explore, associate, and communicate (Hosnan, 2014; Lammers, Goedhart, \& Avraamidou, 2019).

\section{Cirsa Learning Model}

Cirsa learning model is a cooperative learning model developed by Djamahar, Ristanto, Sartono, Ichsan \& Muhlisin (2018). Cirsa model is the development of CIRC model based on scientific approach. In the 2013 Curriculum, teachers are expected to use a scientific approach in learning process. The Cirsa model is developed with principles containing in the CIRC learning model and emphasizing reading process, which is a preferred process in learning (Djamahar, Ristanto, Sartono, Ichsan \& Muhlisin, 2018). Cirsa model is not only emphasizing reading and writing processes but also scientific activities of observing, asking, trying or experimenting, associating, and communicating (Djamahar et al., 2018; 2019). It has several 
advantages, including it can be used for all content in biology learning since biology learning contains concepts existed in daily life that must be understood through reading activity Djamahar et al., (2018).

Implementation on Cirsa study is adopted from learning sintaks developed by (Djamahar, et al., 2018; 2019; Ristanto, et al., 2020). First stage is forming heterogenous group (4 to 5 students). Students are treated with comprehension on Cirsa model, then observing video on excretory system. Second stage of learning is promoting students to explore reading on text or articles about the system. Trough group discussion, students read, discuss and analyze the passage. Discussion result about concept analysis in excretory system will then write on students' worksheet. Rewriting activity will help student to gain understanding on Biology concept better (Harahap, et al., 2020; Ristanto, et al., 2020; Djamahar et al., 2020). Last stage of Cirsa is presentation on discussion result about excretory system. Presentation was done by group which has been selected randomly. Activity is then continue by class discussion on question arise about excretory system.

Various studies have been conducted to study the effectiveness of CIRC and Cirsa learning models in biology learning (Dewi et al., 2018; Ristanto et al., 2018b; Djamahar et al., 2019). Research on the excretory system in junior high school students has been conducted (Djamahar et al., 2019; Djamahar, et al., 2020; Ristanto, et al., 2020). However, there is no research that addresses the effectiveness of the Cirsa learning model in the excretory system in high schools. Based on that, study is needed to be conducted which can clearly explain the effect of Cirsa on students' comprehension on excretory system. This study aims to analyze the Cirsa learning model of conceptual understanding on excretory system in senior high school students. The study should also investigate Cirsa implementation and analyze the response of students'.

\section{Methods}

\section{Research Model}

Method used in the research was quasi-experiment with pre-test - post-test control group design. The research design consisted of two groups, experimental class and control class group. Learning in the experimental class is applied by Cirsa model. Cirsa learning model has three main steps. First, students are heterogeneous in groups. Second, students read comprehensively, discuss and find the main topics in the article. The third step is group presentation. Whereas in the control class applied conventional learning. Conventional learning is learning that is usually applied by teachers. (Ristanto, et al., 2018). The design is illustrated in Table 1.

Table 1. Pretest - Posttest Control Group Research Design.

\begin{tabular}{ccc}
\hline Pretest & Treatment & Postest \\
\hline $\mathrm{O}_{1}$ & $\mathrm{X}$ & $\mathrm{O}_{3}$ \\
$\mathrm{O}_{2}$ & $\mathrm{C}$ & $\mathrm{O}_{4}$ \\
\hline
\end{tabular}

Note:

$\mathrm{O}_{1-} \mathrm{O}_{3}$ : $\quad$ pretest score of learners' concept understanding on excretory system content

$\mathrm{O}_{2}-\mathrm{O}_{4}$ : $\quad$ posttest score of learners' concept understanding on excretory system content

$X: \quad$ experimental class treatment with Cirsa learning model

C: $\quad$ control class with conventional learning 


\section{Sample}

The research was conducted at State Senior High Scholl 5 Depok, Indonesia, in $11^{\text {th }}$ grade of Mathematics and Science Class (MSC) in 2019. The research used the quasiexperiment method. The independent research variable was Cirsa learning model, whereas the dependent variable was conceptual understanding of excretory system. The research sample consisted of 34 students of $11^{\text {th }}$ grade (MSC-4) as experimental class and 34 students of $11^{\text {th }}$ grade of MSC-3) as control class. The samples were selected using simple random sampling technique. The sample selection was done with class equity consideration. The equality test was carried out on 4 classes of MIA were using an average rating on the biological value obtained in the previous material. The results of the equality test showed the MIA 3 and MIA 4 classes are equal. Furthermore, the determination of the experimental class and the control class were carried out randomly accompanied by a biology teacher. The results of the equality test are also seen in the pretest which shows that the experimental and control classes (Table 11).

\section{Instrument}

The instruments in this study consisted of two types, namely the test instrument and the non-test instrument (questionnaire and observation sheet). The main instrument was used to measure the understanding of the excretion system and the observation and questionnaire instruments were used to measure the performance of learning and student responses to learning. Instruments used are conceptual understanding tests of excretory system referring to Bloom's revised taxonomy of $\mathrm{C} 1$ to $\mathrm{C} 6$ consisted of 12 questions. Instrument on concept understanding was essay and open ended. The grid of questions can be seen in Table 2 .

Table 2. Grid of Conceptual Understanding of Excretory System

\begin{tabular}{clcc}
\hline Num & \multicolumn{1}{c}{ Indicator } & $\begin{array}{c}\text { Level of } \\
\text { Cognitive }\end{array}$ & $\begin{array}{c}\text { Number of } \\
\text { Questions }\end{array}$ \\
\hline 1 & $\begin{array}{l}\text { Explain the function and explain the organs making up the } \\
\text { excretion system. }\end{array}$ & C2 & 1 \\
2 & $\begin{array}{l}\text { Analyzing the relationship between the structure of the } \\
\text { constituent nephron tissue in the kidney and its bioprocess and } \\
\text { function. }\end{array}$ & C3 & C4 \\
3 & $\begin{array}{l}\text { Analyzing the process of formation of urine. } \\
\text { analyze the relationship between the structure of the liver and } \\
\text { its bioprocess and its functions. }\end{array}$ & C1, C5 & 2 \\
5 & $\begin{array}{l}\text { Analyze the relationship between the structure of lung tissue } \\
\text { and its bioprocess and function. }\end{array}$ & C6 & 1 \\
6 & $\begin{array}{l}\text { Analyzing the relationship between the structure of the } \\
\text { constituent skin tissue and bioprocess and its function. }\end{array}$ & C3, C5 & 2 \\
7 & Analyzing abnormalities or disorders in the excretory system. & C4, C4, C6 & 3 \\
\hline
\end{tabular}

The third indicator, the $\mathrm{C} 1$ and $\mathrm{C} 5$ levels were distinguished, at the $\mathrm{C} 1$ level students were asked to explain the function of the bilirubin and biliverdin pigments contained in the liver. At C5 level students were given a case related to someone who has abnormalities in the liver then it was characterized by symptoms of nausea, changes in eye and skin color, dark urine and pale stools. Students were asked to evaluate and make an analysis related to the cause of the disease.

In the sixth indicator, two cognitive levels were measured, namely C3 and C5. At the C3 level students were asked to explain the function of the epidermis and dermis in daily life. At C5 level students were given a case related to badminton, students were asked to evaluate the relationship between sports and sweat. In indicator 7 given two different levels of knowledge of the excretion 
system. At the $\mathrm{C} 4$ level students were asked to analyze about the urine test case based on its constituent components, and at the C6 level students were asked to make a thought about kidney function in case of abnormalities.

Instruments are valid if they could appropriately reveal data from the studied variables. Validity test of concept understanding instruments used Pearson Product Moment. The . The decision making was set if $r$ calculate $\geq r$ table, so the instrument items were valid, if $r$ calculate $<r$ table, then the instrument items were not valid. Based on the validity test results, 12 question items were valid. The reliability test of concept understanding used Alpha-Cronbach. The test results obtained $\mathrm{r}$ calculate of 0.7856 and included in high criteria.

The observation sheet of the implementation of learning is a non-test instrument developed in the form of a checklist referring to the syntax of the Cirsa learning model for the experimental class and conventional learning for the control class based on the learning implementation plan. Observation sheet of the implementation of learning is filled in by the observer during the excretion system learning activities.

Response questionnaire is a non-test instrument in the form of a statement to determine students' responses during the learning process of the Cirsa model. Questionnaire responses of students grid can be seen in Table 3 .

Table 3. Questionnaire Grid of Students' Response on Cirsa model.

\begin{tabular}{lc}
\hline Indicator & Item number \\
\hline Acknowledge students' response on Biology learning & $1,2,3,4,5,6$ \\
\hline $\begin{array}{l}\text { Acknowledge students' response on Biology learning with Cirsa } \\
\text { model }\end{array}$ & $7,8,9,10$ \\
\hline $\begin{array}{l}\text { Acknowledge students' response on learning activity with Cirsa } \\
\text { model. }\end{array}$ & $11,12,13,14,15$ \\
\hline $\begin{array}{l}\text { Acknowledge students' response on Biology learning } \\
\text { implementation with Cirsa model. }\end{array}$ & $16,17,18,19,20$ \\
\hline
\end{tabular}

The assessment of students' responses to Cirsa learning was converted in the form of a percentage and interpreted by the categories refer to Table 4.

Tabel 4. Students' response categories to Cirsa learning.

\begin{tabular}{cc}
\hline Percentage $(\boldsymbol{\%})$ & Criteria \\
\hline $0-20$ & very not good \\
$21-40$ & not good \\
$41-60$ & quiet good \\
$61-80$ & good \\
$81-100$ & very good \\
\hline
\end{tabular}

Sources: Riduwan \& Sunarto (2015)

The implementation of the learning on excretion system was carried out four times and divided into four groups of learning topics. The four topics were the functions and organs of the excretory system, the mechanism of formation of urine, the mechanism of excretion in the liver, lungs and scalp and abnormalities in the excretory system. The implementation of the Cirsa learning model was divided into three stages. The first was the equalization of perceptions about the implementation of the Cirsa learning model, group formation as the basis of cooperative learning. At this stage students were given the opportunity to observe a video about the 
structure, organs and mechanisms of excretion. The second stage was students guided by the teacher to conduct exploration activities to find readings or articles related to the excretion system. At this stage students were given the opportunity to read, discuss, and analyze reading. The results of the discussion were developed in the form of an analysis of the concept of an excretion system material in the form of reading titles, sources of articles, learning objectives, important facts, questions that arise, the main concepts and responses. At the end, students are asked to write a reflection of learning activities. The final stage of the learning activity is the presentation of the results of discussions about the excretion system.

\section{Data Collection}

In the preparation, stage samples were determined for experimental and control classes. The next stage was preparing syllabus, Cirsa model learning plan, student worksheet, and research instruments in the form of concept understanding test that had been tested for its validity and reliability. In the implementation stage, a pretest was conducted on experimental and control classes aimed to find out the initial condition of students' conceptual understanding of the excretory system. Next, the posttest was also conducted in both classes to find out the result of conceptual understanding so that the influence of Cirsa learning model could be discovered. In the data processing stage, the results of pretest and posttest were analyzed to know the influence of Cirsa learning model.

\section{Data Analysis}

Data analysis used in the study was a descriptive test in the form of averages and standard deviations. Descriptive testing was also done based on the minimum completeness criteria (MCC) that have been formulated by the school which is 75. Students who exceed the limits were declared to have thoroughly studied the excretion system. Data analysis also includes prerequisites and hypothesis testing. The analysis prerequisite test was a test of normality and homogeneity, while the hypothesis test used the t test, normalized gain test to determine the effect of Cirsa learning models on the understanding of the excretion system concept. The results of the analysis also use the effect size of two groups (Cohen, et al, 2007) to find out to determine the effectiveness of the Cirsa learning model for students. The results of observations of the implementation of learning and student responses to Cirsa learning were analyzed in the form of percentages.

\section{Results and Discussion}

\section{Description of Excretory System Concept Understanding Data}

Data obtained from the experimental and control classes were the result of the excretory system concept understanding test consisted of pretest and posttest. The tests were conducted to 68 learners. Data description on concept understanding for both classes is presented in Table 5 .

Table 5. Description of Concept Understanding Data.

\begin{tabular}{llccc}
\hline \multirow{2}{*}{ Data } & \multicolumn{2}{c}{ Experimental Class } & \multicolumn{2}{c}{ Control Class } \\
\cline { 2 - 5 } & Pretest & Posttest & 83.00 & Posttest \\
\hline Maximum score & 77.00 & 98.00 & 22.00 & 93.00 \\
Minimum score & 14.00 & 58.00 & 43.71 & 47.00 \\
Average & 49.09 & 78.79 & 15.87 & 66.94 \\
Standard Deviation & 14.11 & 10.16 & & 13.10 \\
\hline Normalized Gain $(\%)$ & \multicolumn{5}{c}{$\mathbf{5 8 . 0 0}$} & $\mathbf{4 1 . 0 0}$ \\
\hline
\end{tabular}


In Table 3, the average pretest and posttest scores for the experimental class were higher than the control class. The score of minimum completeness criteria (MCC) of SMA Negeri 5 Depok for biology subject is 75. Based on the MCC score, the results of the conceptual understanding test on excretory system content were indicated in Table 6.

Table 6. Percentage of Conceptual Understanding on excretory system Test Results.

\begin{tabular}{cccccc}
\hline \multirow{2}{*}{ MCC } & \multicolumn{2}{c}{ Experimental Class } & \multicolumn{2}{c}{ Control Class } & \multirow{2}{*}{ Description } \\
\cline { 2 - 5 } & Pretest (\%) & Posttest (\%) & Pretest (\%) & Posttest (\%) & \\
\hline$<75$ & 97.00 & 32.00 & 97.00 & 68.00 & $\begin{array}{c}\text { Did not } \\
\text { complete } \\
\end{array}$ \\
& 3.00 & 68.00 & 3.00 & 32.00 & Completed \\
\hline
\end{tabular}

Based on Table 4, the experimental and control classes experienced an increase in pre-test and post-test scores. The experimental class obtained higher completeness than the control class.

\section{Descriptive data on Excretory System Conceptual Understanding}

Average Score based on concept understanding aspect was obtained from the pretest and posttest results in experimental and control classes. The descriptive data based on the pretest and postest of concept understanding aspects can be seen Table 7.

Table 7. Descriptive data of pretest postes based on Excretory System Conceptual Understanding

\begin{tabular}{|c|c|c|c|c|c|c|c|c|c|}
\hline \multirow{3}{*}{ Indicator } & \multirow{3}{*}{$\mathbf{N}$} & \multicolumn{4}{|c|}{ Experiment Class } & \multicolumn{4}{|c|}{ Control Class } \\
\hline & & \multicolumn{2}{|c|}{ Pretest } & \multicolumn{2}{|c|}{ Posttest } & \multicolumn{2}{|c|}{ Pretest } & \multicolumn{2}{|c|}{ Posttest } \\
\hline & & Mean & SD & Mean & SD & Mean & SD & Mean & SD \\
\hline $\mathrm{C} 1$ & 34 & 66.71 & 29.44 & 83.82 & 17.27 & 72.79 & 23.32 & 86.76 & 20.62 \\
\hline $\mathrm{C} 2$ & 34 & 46.32 & 28.95 & 88.89 & 19.64 & 61.02 & 28.33 & 87.50 & 25.56 \\
\hline $\mathrm{C} 3$ & 34 & 61.76 & 24.92 & 80.68 & 14.00 & 56.24 & 23.55 & 74.26 & 20.18 \\
\hline $\mathrm{C} 4$ & 34 & 51.72 & 21.73 & 79.04 & 24.24 & 45.21 & 21.33 & 65.07 & 26.09 \\
\hline C5 & 34 & 36.39 & 27.75 & 76.47 & 25.33 & 23.16 & 23.28 & 57.35 & 25.60 \\
\hline C6 & 34 & 41.17 & 24.41 & 73.52 & 22.40 & 28.30 & 25.30 & 55.51 & 29.32 \\
\hline \multicolumn{2}{|c|}{ Average } & 50.58 & 26.20 & 80.40 & 20.48 & 47.78 & 24.18 & 71.07 & 24.56 \\
\hline
\end{tabular}

According to Table 7, the average scores based on the pretest of concept understanding aspect indicated that the results in experimental class had higher scores in the C3, C4, C5, and $\mathrm{C} 6$ aspects. In contrast, in the control class, the higher scores were in $\mathrm{C} 1$ and $\mathrm{C} 2$ aspects. The average scores based on posttest of concept understanding aspects indicated that the experimental class had higher scores in C2, C3, C4, C5, and C6 aspects. In contrast, it was only $\mathrm{C} 1$ aspect that had higher score in the control class.

\section{Results of Learning Implementation}

The learning implementation results in the experimental and control classes were displayed in Figure 1. 


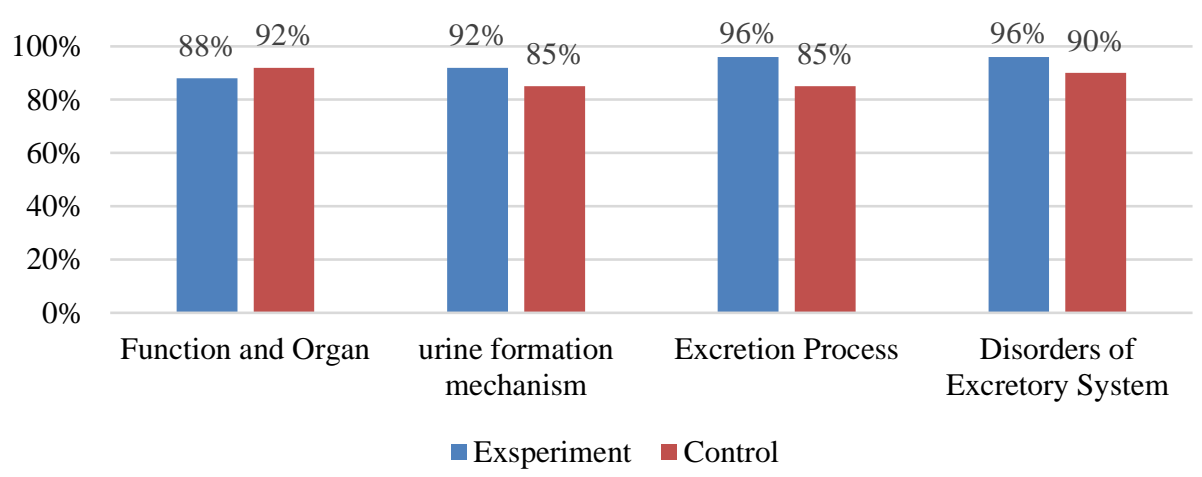

Figure 1. Learning Implementation in Experimental and Control Classes

The learning implementation was observed by referring to learning model application steps conducted in the experimental and control classes. Referring to Figure 1, it can be seen that the average learning implementation in the experimental class was higher than the control class, which was $93 \%$ and $88 \%$, respectively. According to Riduwan \& Sunarto (2015), the implementation category of both classes was within good criteria. Figures 2, 3, and 4 show sample students are answering the conceptual question understanding of the excretory system.

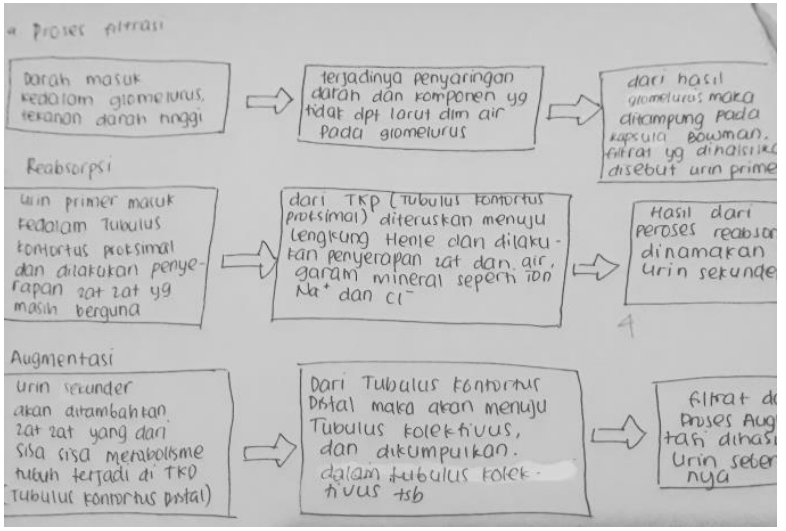

Figure 2. Sample of answer student with the indicator to analyzing the urine formation process.

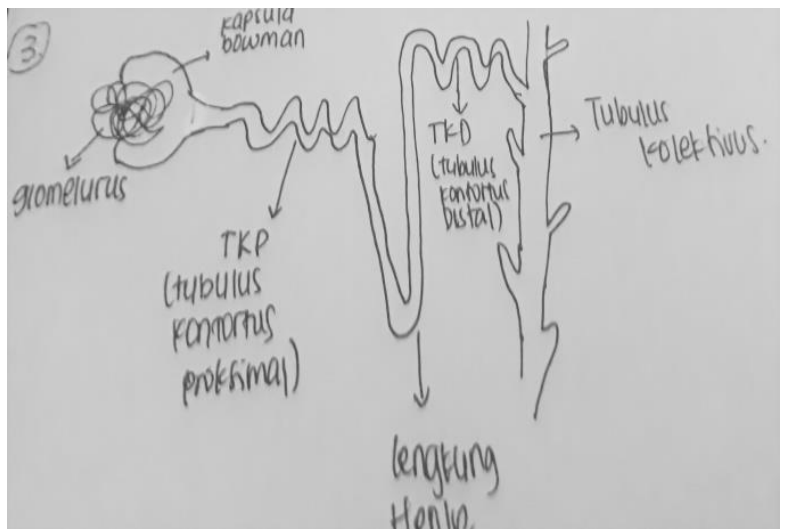

Figure 3 Sample of answer student with indicator Analyze link between nephron tissue structures in the kidney along with its bioprocess and functions (C3).

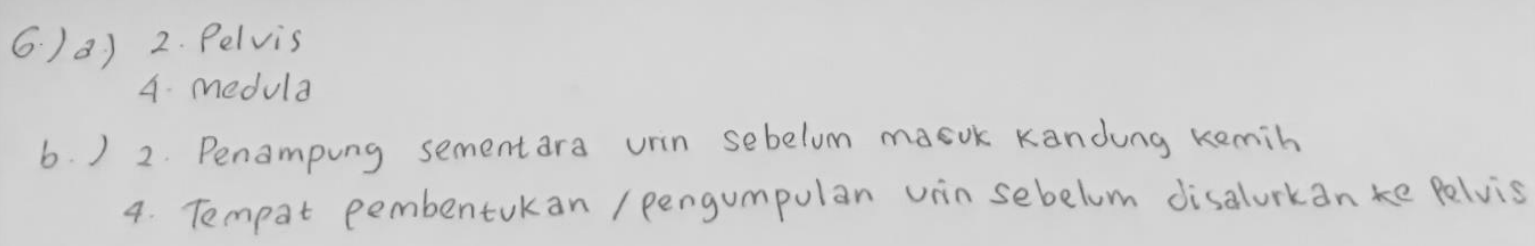

Figure 4. Sample of answer student with indicator explains the excretory system functions and identify the excretory system organs (C2). 


\section{Results of Learners' Response Questionnaires}

Learners' response questionnaire aimed to find out learners' responses to biology learning using Cirsa model. The results of response questionnaire are described in Table 8 and Figure 5.

Table 8. Results of Students' Response Questionnaire

\begin{tabular}{|c|c|c|c|c|}
\hline Num & Questions & Total & $\%$ & Category \\
\hline Q1 & I prefer biology subject to other subjects. & 94 & 69 & Good \\
\hline Q2 & Biology is a fun subject. & 97 & 71 & Good \\
\hline Q3 & Biology is one of the compulsory subjects. & 110 & 81 & Very good \\
\hline Q4 & Biology is useful in daily life. & 114 & 84 & Very good \\
\hline Q5 & $\begin{array}{l}\text { Biology subject is quite troublesome since it requires special } \\
\text { preparation. }\end{array}$ & 107 & 79 & Good \\
\hline Q6 & Biology could not be applied in daily life. & 120 & 88 & Very good \\
\hline Q7 & Learning Biology using Cirsa model is not exciting and is boring. & 110 & 81 & Very good \\
\hline Q8 & $\begin{array}{l}\text { Learning Biology using Cirsa model makes me interested, and it is not } \\
\text { boring. }\end{array}$ & 90 & 66 & Good \\
\hline Q9 & Cirsa learning makes me lazy to listening to the lesson. & 118 & 87 & Very good \\
\hline Q10 & Cirsa learning is not different from regular learning. & 77 & 57 & Fair \\
\hline Q11 & Cirsa learning makes me easy to understand the content. & 96 & 71 & Good \\
\hline Q12 & Cirsa model allows applying biology in daily life. & 94 & 69 & Good \\
\hline Q13 & $\begin{array}{l}\text { Teaching materials presented makes it difficult to understand the } \\
\text { content. }\end{array}$ & 101 & 74 & Good \\
\hline Q14 & Cirsa learning encourages me to argue. & 98 & 72 & Good \\
\hline Q15 & I prefer learning biology using Cirsa model to the regular learning. & 100 & 74 & Good \\
\hline Q16 & $\begin{array}{l}\text { I am happy with biology learning using Cirsa model since I could } \\
\text { exchange ideas with my friends. }\end{array}$ & 106 & 78 & Good \\
\hline Q17 & Biology learning with Cirsa model is useless for me. & 111 & 82 & Very good \\
\hline Q18 & I feel tense and depressed during biology learning. & 127 & 93 & Very good \\
\hline Q19 & Learning by discussion makes me hard to understand the content. & 107 & 79 & Good \\
\hline Q20 & I feel motivated to learn Biology after I learn using Cirsa model. & 121 & 89 & Very good \\
\hline
\end{tabular}

Note: maximal value is 136 .

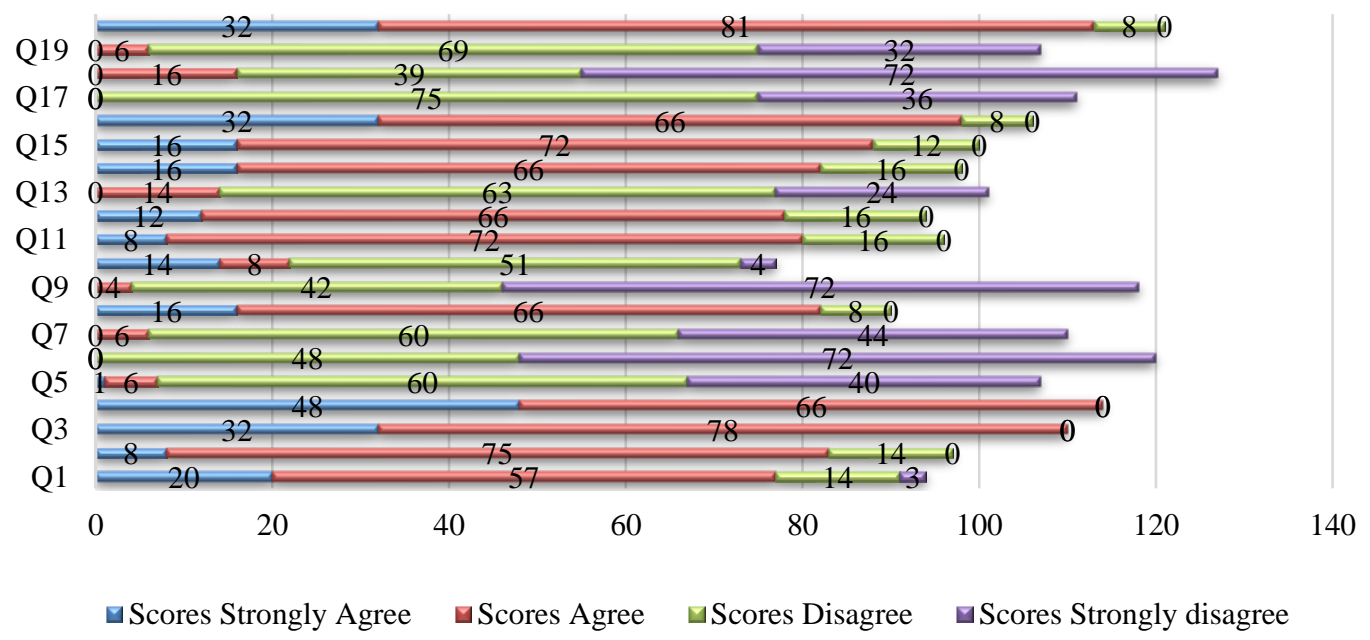

Figure 5. Results of Students' Response Questionnaire 


\section{Results of Normality and Homogeneity Tests}

Prerequisite tests consisted of normality tests using Kolmogorov-Smirnov and homogeneity test using F-test at $\alpha=0.05$. The calculation used SPSS Version 25. Data are normally distributed if the significance value is more than $\alpha$. The results of normality test could be seen in Table 9 .

Table 9. Normality Test.

\begin{tabular}{lcccc}
\hline Class & Test Result & Sig. & $\boldsymbol{\alpha}$ & Description \\
\hline Experiment & Pretest & 0.200 & 0.05 & Normal \\
& Posttest & 0.200 & 0.05 & Normal \\
\cline { 2 - 5 } Control & Pretest & 0.200 & 0.05 & Normal \\
& Posttest & 0.139 & 0.05 & Normal \\
\hline
\end{tabular}

Based on Table 9, it can be seen that all data were normally distributed. In the homogeneity test, data are homogeneous if the significance value is more than $\alpha$. The results of the homogeneity test indicated that all data came from homogeneous population. The results of the homogeneity test are presented in Table 10.

Table 10. Homogeneity Test

\begin{tabular}{lcccc}
\hline Class & Test Result & Sig. & $\boldsymbol{\alpha}$ & Description \\
\hline Experiment & Pretest & 0.415 & 0.05 & Homogeneous \\
& Posttest & 0.067 & 0.05 & Homogeneous \\
\cline { 2 - 5 } Control & Pretest & 0.415 & 0.05 & Homogeneous \\
& Posttest & 0.067 & 0.05 & Homogeneous \\
\hline
\end{tabular}

\section{Hypothesis Testing}

The hypothesis testing used Independent t-test of pretest, posttest data, and gain score to find out the influence of Cirsa model on excretory system concept understanding. The calculation of independent t-test used SPSS version 25. A criterion to reject $\mathrm{H} 0$, which is there is an influence of Cirsa model on excretory system concept understanding, is if the significance value is less than $\alpha$. The results of independent t-test on pretest data of excretory system concept understanding are presented in Table 11.

Table 11. Independent t-test of Concept Understanding Pretest.

\begin{tabular}{lllllll}
\hline Group & $\mathbf{N}$ & $\overline{\boldsymbol{X}}$ & SD & Sig. & $\boldsymbol{\alpha}$ & Description \\
\hline Experiment & 34 & 49.09 & 14.11 & 0.144 & 0.05 & Sig. $>0.05$ \\
Control & 34 & 43.71 & 15.87 & 0.144 & 0.05 & Sig. $>0.05$ \\
\hline
\end{tabular}

The result of pretest calculation obtained that $\rho$ was higher than $\alpha$ with significance value of 0.144 or greater than 0.05 ; therefore, it can be concluded that $\mathrm{H}_{0}$ was accepted. It means there was an average difference in concept understanding of the excretory system. The independent t-test of posttest data can be seen in Table 12.

Table 12. Independent t-test of Concept Understanding Posttest.

\begin{tabular}{lllllll}
\hline Group & $\mathbf{N}$ & $\overline{\boldsymbol{X}}$ & SD & Sig. & $\boldsymbol{\alpha}$ & Description \\
\hline Experiment & 34 & 78.79 & 10.16 & 0.000 & 0.05 & Sig. $<0.05$ \\
Control & 34 & 66.94 & 13.10 & 0.000 & 0.05 & Sig. $<0.05$ \\
\hline
\end{tabular}

The result of the posttest t-test calculation resulted in that $\rho$ was less than $\alpha$ with a significance value of 0.000 or less than 0.05 ; therefore, it can be inferred that $\mathrm{H}_{0}$ was rejected. It means that there was an average difference, so the Cirsa model influenced the excretory system concept 
understanding.

Table 13. Independent t-test of Concept Understanding Gain score.

\begin{tabular}{llccccc}
\hline Group & $\mathbf{N}$ & $\overline{\boldsymbol{X}}$ & SD & Sig. & $\boldsymbol{\alpha}$ & Description \\
\hline Experiment & 34 & 29.70 & 12.31 & 0.039 & 0.05 & Sig. $<0.05$ \\
Control & 34 & 23.23 & 12.94 & 0.039 & 0.05 & Sig. $<0.05$ \\
\hline
\end{tabular}

The result of gain score t-test calculation (Table 13) suggested that $\rho$ was less than $\alpha$ with significance value of 0.039 or less than 0.05 ; thus, $\mathrm{H}_{0}$ was rejected. It means that there was an average difference, so the Cirsa model influenced the conceptual understanding of excretory system.

\section{Normalized Gain Test}

The normalized Gain test was conducted to find out the difference between pretest and posttest in both experimental and control classes as well as the effectiveness of learning model. The Normalized Gain test result can be seen in Table 14.

Table 14. Normalized Gain Test.

\begin{tabular}{lccccl}
\hline Class & $\overline{\boldsymbol{X}}$ Gain & $\overline{\boldsymbol{X}}$ Normalized & Description & $\overline{\boldsymbol{X}}$ Normalized Gain (\%) & Description \\
\hline Experiment & 29,70 & 0,58 & Medium & 58,00 & Fairly Effective \\
Control & 23,23 & 0,41 & Medium & 41,00 & Less Effective \\
\hline
\end{tabular}

The results of gain score and normalized gain calculation in the experimental class were larger than the control class. Regarding the effectiveness level, the experimental class with Cirsa learning model was somewhat effective compared to the control class using conventional learning. The results of the effect size analysis are performed on each indicator of excretion system concept mastery. A summary of the results of the effect size analysis is shown in Table 15 .

Table 15. Effect size on Excretory system in experiment and control class

\begin{tabular}{lcccc}
\hline Indicator & Effect Size of pretest & Description & Effect Size of postest & Description \\
\hline Remembering (C1) & 0.23 & Small & 0.12 & Small \\
Understanding (C2) & 0.51 & Medium & 0.10 & Small \\
Applying (C3) & 0.23 & Small & 0.37 & Small \\
Analyzing (C4) & 0.41 & Small & 0.55 & Medium \\
Evaluating (C5) & 0.51 & Medium & 0.70 & Medium \\
Creating (C6) & 0.51 & Medium & 0.68 & Medium \\
\hline
\end{tabular}

in excretory system content. The results of hypothesis testing in gain score using independent t-test indicated that there was an influence of Cirsa model on excretory system concept understanding. According to average gain score, the experimental class obtained higher results than the control class. It was due to the implementation of Cirsa learning model was somewhat effective compared to conventional learning. The research was relevant to Djamahar et al. (2019) opined that there was an influence of Cirsa learning model on conceptual understanding of excretory system.

The average scores based on concept understanding aspects in pretest data were illustrated in Table 7. The experimental class obtained higher scores in applying, analyzing, evaluating, and creating aspects. The class control gained higher scores in remembering and understanding aspects. It was related to the excretory system that had been taught at the junior high school 
level; thus, most learners still remember the content. Based on cognitive theory, learners who have gained prior understanding will keep the understanding in their memory (Siregar \& Nara, 2010; Sele, 2019).

The average scores based on posttest of conceptual understanding aspects could be seen in Table 7. The results indicated that the experimental class had higher scores in understanding, applying, analyzing, evaluating, and creating aspects. The control class, however, had higher scores in remembering aspect. Based on minimum completeness criteria, none of the classes, the experimental and control classes, that met the criteria in remembering up to evaluating aspects of pretest; thus, it can be assumed that the concept understanding ability of both classes was equal. In the posttest, however, the experimental class met the criteria in remembering up to evaluating indicators, whereas in the control class, it was only remembering and understanding that completed. It was due to the average of posttest results of conceptual understanding in the experimental class that was higher than the control class, which proved that there was an influence of Cirsa learning on conceptual understanding of excretory system.

The influence of excretory system learning improvement could be analyzed according to Cirsa model learning syntax, including group division, reading, discussion, finding the main concept of articles, and presentation activities. Students observed videos or pictures on the content. Observing activity includes in scientific approach (Suyanto, 2018). It is in line with Daryanto \& Karim (2017); Darmawan et al., (2019) that observing activity is useful to foster learners' curiosity in the learning process (Djamahar et al., 2019; Ningrum, 2009).

The first step in the Cirsa learning model application in the research was teacher formed groups of 4-5 students heterogeneously. The group formation aimed to have each learner to be responsible to the group duties and able to exchange ideas so as the same understanding could be established. Group learning could improve understanding due to the occurrence of cooperation between group members, and learners are more active during the learning process so as they could understand the concept given (Brown, 2010; Trilipi et al., 2019). Students working in a group assignment, learners exchange opinions and ideas to understand a concept so as understanding formed during the learning (Ristanto et al., 2018b; Indriani, \& Mercuriani, 2019).

Teachers gave articles to learners on excretory functions and organs, urine formation mechanisms, excretory mechanisms in skin, and abnormalities in excretory system. The purpose of this activity was related to Cirsa learning model that emphasizes reading and writing activities. According to Djamahar et al. (2019) and Ristanto et al. (2019), Cirsa learning model emphasizes reading activity since it could build learner way of thinking. The reading activity could understand the meaning of a reading (Hayati et al., 2015; Sele, 2019; Sastrika, 2013). The characteristics of articles given included writing a concept or main idea and important facts and making questions about excretory system.

The second step of Cirsa learning is learners reading, discussing, and understanding the articles given. It is by scientific approach stage, which is learner performs exploration activity. In line with Hosnan (2014), exploration activity aims to involve learners to be active in a discussion. Students read on content so that they could explain the system functions and organs making up the excretory system, analyze link between nephron tissues in kidney along with its bioprocess and function, analyze urine formation, analyze link between compiler tissues in the liver, lung, and skin along with their bioprocess and functions and analyze abnormalities in excretory system. Reading was a necessity in the excretory system content since the content required well 
understanding of the concept. Masupah, Hidayat \& Latifah (2017) opined that excretory system content has interrelated concepts, and it will be difficult to understand if learning is conducted conventionally. Reading activity on articles given by the teacher allows learners to understand the content well. That reading activity could improve vocabulary understanding ability, thus the formation of understanding (Durukan, 2011; Prawita \& Prayitno, 2019).

After reading the article, students rewrote it using their own words. They wrote about the main concepts and important facts and made questions about excretory organs, excretory system functions, urine formation mechanism in the kidney, the excretory mechanism in skin organ, and analyzed abnormalities of excretory system in the kidney. The scientific approaches conducted included associating and asking (Ristanto \& Djamahar, 2019). Associating activity is performed to analyze information obtained so as conclusions could be drawn, whereas asking could develop thinking ability Daryanto \& Karim, 2017; Mustafa \& Samad, 2015). Associating activity is useful to train learners to analyze a concept and draw a conclusion, whereas asking activity is useful to improve curiosity in the learners and involves the active learning process (Sani \& Hayati, 2018; Ganarsih, 2018). Learning activity that involves finding important facts and rewrite them with their own words allows learners to be active in learning (Gupta \& Ahuja, 2014; Djamahar et al., 2019; Ristanto, 2018b).

Rewriting the reading with its own words allows learners to have more understanding of content given by the teacher and store the information for a long time (Al-Mansour, \& Al-Shorman, 2014). Make a summary after reading could improve reading understanding ability (Zarei, 2012; Ristanto, 2018b). Writing activity could store information for an extended period (Mueller \& Oppenheimer, 2014). Rewriting the main ideas of reading would facilitate understanding of concepts contained in the content. It is relevant to Hayati et al., (2015) research that writing the main ideas in reading will help learners to remember the reading outline; hence, it could improve cognitive learning outcomes. Reading and writing activities make learners better understand the content presented during the learning (Yeni, Yekhebed \& Kulsum, 2012; Leasa et al., 2019).

The third step was presenting the discussion result in front of the classroom. Discussion activity encourages learners to express their opinion. They communicate the discussion result through presentation. The communicating activity includes scientific approach steps. Students who dare to express their opinion will have excellent communication skills (Hosnan, 2014; Mueller \& Oppenheimer, 2014). Communication skill is a must-owned skill for learners to be brave to express their own opinion (Sani \& Hayati, 2018; Leasa et al., 2019 ). Teachers guide learners to discuss and ask questions between groups and then provide strengthening. Students then conclude the studied content. Presentation activity could train learners to express their own opinion. Discussion and presentation activities could improve communication skills (Zivkovic, 2014; Zubaidah \& Corebima, 2016).

Based on the result of learning implementation indicated in Table 7, it can be seen that the average of the experimental class was higher than the control class since the learning implementation syntax in the experimental class was well implemented compared to the control class. The result of learning response questionnaire, as presented in Table 8 and Figure 5, proved that students were interested in Cirsa learning model since it is different from the commonly applied learning model. The cirsa learning model used articles during the learning process. Learning using Cirsa allowed learners to discuss together, dare to express their opinion, and it was easier for them to understand the content. 
The application of Cirsa learning in the experimental class had proven to improve the conceptual understanding of excretory system. Cirsa learning model involves learners to be active in such activities as reading, discussing, rewriting, and communicating the discussion results; thus, it is effective in improving biology concept understanding Ristanto et al., (2018b). One of Cirsa learning advantages includes it could be used for all contents in biology learning. Biology learning requires reading activity to understand the concept (Djamahar et al., 2018; Lestari et al., 2019). The current research had strength; namely, the learning implementation was achieved in each syntax, including group formation activity, reading articles, rewriting main concepts, essential facts, making questions, discussion, and group presentation. The research also had some limitations, namely: learners were not familiar with the use of Cirsa learning model in the learning, and a right time allocation arrangement is required in implementing Cirsa learning model to obtain optimal results.

\section{Conclusion}

Based on the research results, there was an influence of Cirsa learning model on concept understanding of excretory system content. The Cirsa learning model was proven to be effective in improving conceptual understanding of excretory system content compared to conventional learning. It could be applied in learning to improve the conceptual understanding of excretory system.Teachers and learners need to understand more about the Cirsa model so that learning process in the excretory system content will be more optimal. Right time allocation also crucial in implementing the model.

\section{Acknowledgments}

The authors would like to thank teachers and students of State Senior Highschool 5 of Depok, Indonesia, who had helped the research process. We would also like to thank Mrs. Yulilina Retno Dewahrani, M.Biomed, Mrs. Nurmasari Sartono, M.Biomed, and Dr. Diana Vivanti Sigit for their inputs in the research process.

\section{References}

Al-Mansour, N. S., \& Al-Shorman, R. A. (2014). The effect of an extensive reading program on the writing performance of saudi efl university students. International Journal of Linguistics, 6(2), 247.

Anderson, L.W \& Krathwohl, D.R. (2001). A Taxonomy for Learning, Teaching and Assessing: A Revision of Bloom's Taxonomy of Educational Objectives. New York: Addison Wesley Longman.

Brown, P.J.P. (2010). Process oriented guided inquiry learning in an introductory anatomy and physiology course with a diverse student population. Advan in Physiol Edu,34 (2), 150155.

Bustami, Y., Riyati, Y., \& Julung, H. (2019). Think talk write with pictured cards on human digestive system: impact of critical thinking skills. Biosfer: Jurnal Pendidikan Biologi, 12(1), 13-23.

Cimer, A. (2012). What makes biology learning difficult and effective: students views. Educational Research and Reviews, 7(3), 61-71.

Cohen, L., Manion, L., \& Morrison, K. (2013). Research methods in education. routledge

Darmawan, E., Alamsyah, M. R. N., Permadani, K. G., Pamungkas, S. J., Prajoko, S., Sukmawati, I., ... \& Zamzami, M. R. A. (2019). Integration of Simas eric with google classroom: enhancing biology students motivation and scientific writing. Biosfer: Jurnal Pendidikan Biologi, 12(1), 1-12. 
Daryanto \& Karim, S. (2017). Pembelajaran Abad 21. Yogyakarta: Gaya Media.

Djamahar, R., Ristanto, R. H., Sartono, N., Ichsan, I. Z., \& Muhlisin, A. (2018). CIRSA: Designing Instructional Kits to Empower 21 st Century Skill. Educational Process: International Journal, 7(3), 200-208.

Djamahar, R., Ristanto, R. H., Sartono, N., Ichsan, I. Z., \& Muhlisin, A. (2019). Empowering Student's Metacognitive Skill Through Cirsa Learing. Journal of Physis: International Conference on Mathematics and Science Education.

Djamhar, R., Ristanto, R. H., Sartono, N., \& Darmawan, E. (2020). Approaches to respiratory and excretion systems teaching: an innovative learning through cirsa. Universal Journal of Educational Research, 8 (6), 2204 - 2210.

Durukan, E. (2011). Effect of Cooperative Integrated Reading and Composition (CIRC) Technique on Reading-Writing Skills. Academic Journals, 6(1), 103-110.

Faisal. (2015). Mengintegrasikan Revisi Taksonomi Bloom kedalam Pembelajaran Biologi. Jurnal Sainsmat, 6(2), 102-112.

Garnasih, T. (2018). Kemampuan siswa dalam mengelola extraneous cognitive load pada pembelajaran klasifikasi tumbuhan dengan menggunakan apersepsi tayangan video. Bioeduin: Jurnal Program Studi Pendidikan Biologi, 8(2), 29-33.

Gunawan, I \& Palupi, R.A. (2016). Taksonomi bloom-revisi ranah kognitif: kerangka landasan untuk pembelajaran, pengajaran dan penilaian. Jurnal Premiere Educandum, 2(2), 98117.

Gunel, M., Hand, B., \& McDermott, M. A. (2009). Writing for different audiences: Effects on high-school students' conceptual understanding of biology. Learning and instruction, 19(4), 354-367.

Gupta, M \& Ahuja, J. (2014). Cooperative integrated reading and composition (circ): impact on reading comprehension achievement in english among seventh graders. IMPACT: International Journal of Research in Humanities, Arts and Literature, 2(5), 37-46.

Harahap, L. J., Ristanto, R. H., \& Komala, R. (2020). Getting critical thinking about ecosystem: How impact and responses of students about the CirGi learning model?. Biosfer: Jurnal Pendidikan Biologi, 13(1), 86 - 100.

Hariyadi, S., \& Corebima, A. D. (2019). The distribution of patterns and types of questions in genetic learning implementing reading-questioning-answering learning model. International Journal of Environmental and Science Education, 14(8), 469-477.

Hayati, N., Zubaidah, S., \& Mahanal, S. (2015). Penerapan Model Pembelajaran Biologi berbasis Reading Concept Map Cooperative Integrated Reading and Composition (Remap Circ) untuk Meningkatkan Hasil Belajar Kognitif Siswa Kelas X SMA Malang. Conference Paper, pp. 192-199.

Hamdani, D., Kurniati, E., \& Sakti, I. (2012). Pengaruh model pembelajaran generatif dengan menggunakan alat peraga terhadap pemahaman konsep cahaya kelas viii di smp negeri 7 kota bengkulu. Jurnal Exacta, 10 (1), 79-88.

Hosnan, M. (2014). Pendekatan Saintifik dan Kontekstual dalam Pembelajaran Abad 21. Jakarta: Ghalia Indonesia.

Huda, M. (2013). Model-model Pengajaran dan Pembelajaran: Isu-isu Metodis dan Paradigmatis. Yogyakarta: Pustaka Pelajar.

Huang, Y.M., Liao, Y.W., Huang, S.H., \& Chen, H.C. (2014). A jigsaw-based cooperative learning. Educational Technology \& Society, 17(1), 128-140.

Ichsan, I. Z., Hasanah, R., Aini, S., Ristanto, R. H., \& Miarsyah, M. (2019). Higher order thinking skills assessment based on environmental problem (HOTS-AEP): Mendesain evaluasi pembelajaran abad 21. Jurnal Biotek, 7(1), 14-26.

Ilahi, M.T. (2016). Pendidikan Berbasis Moral. Jakarta: Ar-Ruzz Media. 
Indriani, D., \& Mercuriani, I. S. (2019). Experiential learning model with mind mapping on fungi: how to improve science process skills?. Biosfer: Jurnal Pendidikan Biologi, $12(2), 223-237$.

Kurniawan, A.D. (2013). Metode inkuiri terbimbing dalam pembuatan media pembelajaran biologi untuk meningkatkan pemahaman konsep dan kreativitas siswa smp. Jurnal Pendidikan IPA Indonesia, 2(1), 8-11.

Lammers, A., Goedhart, M. J., \& Avraamidou, L. (2019). Reading and synthesizing science texts using a scientific argumentation model by undergraduate biology students. International Journal of Science Education, 41(16), 2323-2346.

Leasa, M., Sanabuky, Y. L., Batlolona, J. R., \& Enriquez, J. J. (2019). Jigsaw in teaching circulatory system: a learning activity on elementary science classroom. Biosfer: Jurnal Pendidikan Biologi, 12(2), 122-134.

Lestari, P., Ristanto, R. H., \& Miarsyah, M. (2019). Analysis of conceptual understanding of botany and metacognitive skill in pre-service biology teacher in Indonesia. Journal for the Education of Gifted Young Scientists, 7(2), 199-214.

Luzyawati, L., \& Hidayah, H. (2019). Profil miskonsepsi siswa dalam materi sistem ekskresi melalui penugasan peta konsep. Mangifera Edu: Jurnal Biologi and Pendidikan Biologi, 3(2), 72-87.

Masupah, M., Hidayat, A., \& Latifah, R. (2017). Penerapan model pembelajaran cooperatif integrated reading and composition (circ) dengan mind mapping terhadap kemampuan berpikir kritis siswa kelas xi ipa sman 1 bojongsoang. Jurnal Program Studi Pendidikan Biologi UIN SGD, 8(1), 34-42.

Maurisa, A.M. \& Abdullah, H. (2016). Hubungan kemampuan membuat peta konsep dengan hasil belajar siswa di kelas xi pada materi pokok sistem ekskresi manusia. Jurnal Pelita Pendidikan, 4(2), 15-19.

Miarsyah, M., Ristanto, R.H., Nurhayati, Mufida, S.N., Suparini, Zharroh, A.E. (2020). Development of adobe flash media integrated into hots on circulation system (af-hots bicycle media). International Journal of Advanced Trends in Computer Science and Engineering, 9(1), 896-903.

Mueller, P.A., \& Oppenheimer, D.M. (2014). The pen is mightier than the keyboard: advantages of longhand over laptop not taking. Journal of Psychological Science, 25(6), 1159-1168.

Mustafa, F., \& Samad, N. M. A. (2015). Cooperative Integrated Reading and Composition Technique for improving content and organization in writing. Studies in English Language and Education, 2(1), 29-44.

Ningrum, W.N. (2009). Penerapan model pembelajaran pictureand picture untuk mempercepat penyelesaian soal-soal matematis dalam upaya meningkatkan prestasi belajar fisika. Jurnal Pendidikan MIPA, 1(1), 48-53

Nurdyansyah \& Fahyuni, E.F. (2016). Inovasi Model Pembelajaran Sesuai Kurikulum 2013. Sidoarjo: Nizamial Learning Center.

OECD. (2017). PISA 2015 Result (Volume V): Collaborating Problem Solving, PISA. Paris: OECD Publishing.

Prawita, W., \& Prayitno, B. A. (2019). Effectiveness of a generative learning-based biology module to improve the analytical thinking skills of the students with high and low reading motivation. International Journal of Instruction, 12(1), 1459-1476.

Rahmawati, Y., Prayitno, B. A., \& Indrowati, M. (2015). Studi komparasi tingkat miskonsepsi siswa pada pembelajaran biologi melalui model pembelajaran konstruktivisme tipe Novick dan konstruktivis-kolaboratif. Jurnal Pendidikan Biologi, 7(3), 11-26.

Remli, M. A., Mohamad, M. S., Deris, S., Samah, A. A., Omatu, S., \& Corchado, J. M. (2019). Cooperative enhanced scatter search with opposition-based learning schemes for 
parameter estimation in high dimensional kinetic models of biological systems. Expert Systems with Applications, 116, 131-146.

Riduwan \& Sunarto, H. (2015). Pengantar Statistika untuk Penelitian Pendidikan, Sosial, Ekonomi, dan Bisnis. Bandung: Alfabeta.

Ristanto, R.H., Zubaidah, S., Amin, M., \& Rohman, F. (2017). Scientific literacy of students learned through guided inquiry. International Journal of Research and Review, 4(5), 23-30.

Ristanto, R.H., Zubaidah, S., Amin, M., \& Rohman, F. (2018a). From a reader to scientist: developing cirgi learning to empower scientific literacy and mastery of biology concept. Biosfer: Jurnal Pendidikan Biologi, 11(2), 89-99.

Ristanto, R.H., Zubaidah, S., Amin, M., \& Rohman, F. (2018b). The potential of cooperative integrated reading and composition in biology learning at higher education. International Journal of Educational Research Review, 3(1), 50-56.

Ristanto, R. H., \& Djamahar, R. (2019). Penguatan keterampilan penilaian autentik guru ipa biologi di kabupaten bogor. BAKTIMAS: Jurnal Pengabdian pada Masyarakat, 1(1), 61-69.

Ristanto, R. H., Djamahar, R., Heryanti, E., \& Ichsan, I. Z. (2020). Enhancing students' biologycritical thinking skill through circ-based scientific approach (cirsa). Universal Journal of Educational Research, 8(4A), 2204 - 2210.

Sani, R.A. (2018). Pembelajaran Saintifik untuk Implementasi Kurikulum 2013. Jakarta: Bumi Aksara.

Sastrika, I.A.K., Sadia, I.W., \& Muderawan, I.W. (2013). Pengaruh model pembelajaran berbasis proyek terhadap pemahaman konsep kimia dan keterampilan berpikir kritis. E-Journal Program Pascasarjana Universitas Pendidikan Ganesha, 3(3), 1-13.

Sele, Y. (2019). Optimizing the potential of children learning in science (clis) with brain gym: review on human circulatory concepts. Biosfer: Jurnal Pendidikan Biologi, 12(2), 238248.

Siregar, E \& Nara, H. (2010). Teori Belajar dan Pembelajaran. Bogor: Ghalia Indoenesia.

Supriyatin, Rahayu, S., Ristanto, R.H., Ichsan, I.Z. (2019). Improving hots in biology learning: A supplement book of plant growth and development. Universal Journal of Educational Research, 7(12), 2642-2646.

Suyanto, S. (2018). The implementation of the scientific approach through $5 \mathrm{~m}$ of the revised curriculum 2013 in Indonesia. Cakrawala Pendidikan, 37 (1), 22-29.

Tamaya, E., Suyono \& Roekhan. (2018). Membaca menulis sebagai metode belajar analisis meta teori. Jurnal Pendidikan, 3(3), 349-356.

Trilipi, D., Subali, B., Anwar, Y., \& Santoso, L. M. (2019). Note-taking roundhouse diagram strategy: improving student retention on body defense system concepts. Biosfer: Jurnal Pendidikan Biologi, 12(2), 157-169.

Yeni, L.F., Yekhebed., \& Khalsum, U. (2012). Efektivitas model pembelajaran cooperative integrated reading and composition (circ) terhadap hasil belajar siswa pada sub materi pencemaran lingkungan di kelas x sma negeri 4 pontianak. Jurnal Visi Ilmu Pendidikan, 8(2), 803-814.

Yunanda, I., Susilo, H., \& Ghofur, A. (2019). Misconceptions identification on biodiversity and protist using multiple-choice open reason (mcor). Biosfer: Jurnal Pendidikan Biologi, 12(2), 170-181.

Zainudin, M., \& Istiyono, E. (2019). Scientific Approach to Promote Response Fluency Viewed from Social Intelligence: Is It Effective?. European Journal of Educational Research, 8(3), 801-808.

Zarei, A.A. (2012). The Effects of stad and circ on 12 reading comprehension and vocabulary learning. Frontiers of Language and Teaching 3, 161-173. 
Zivkonic, S. (2014). The importance of oral presentations for university students. Mediterranean Journal of Social Sciences, 7(19), 468-475.

Zubaidah, S \& Corebima, D.A. (2016). Remap Coople (Reading-Concept Map-Cooperative Learning). Malang: Aditya Media Publishing. 